\title{
An Overview on the Use of Enhanced Efficiency Nitrogen Fertilizers in Irrigated Mediterranean Agriculture
}

\author{
Alexandra Tomaz ${ }^{1,2 *}$, José Ferro Palma ${ }^{1}$, Isabel Guerreiro ${ }^{1}$, Maria Isabel Patanita ${ }^{1}$, José Penacho ${ }^{1}$, José \\ Dôres $^{1}$, Maria Natividade $\operatorname{Costa}^{1}$, Elisabete Rosa $^{1}$ and Manuel Patanita ${ }^{1,2}$ \\ ${ }^{1}$ Departamento de Biociências, Escola Superior Agrária - Instituto Politécnico de Beja, Portugal \\ ${ }^{2}$ GeoBioTec, Universidade Nova de Lisboa, Portugal
}

Received: December 04, 2017; Published: December 13, 2017

*Corresponding author: Alexandra Tomaz, PhD, Departamento de Biociências, Escola Superior Agrária - Instituto Politécnico de Beja. R. Pedro Soares S/N, 7800-295 Beja, Portugal

\begin{abstract}
In Mediterranean regions climate change has led to greater inter and intra-annual rainfall irregularity, causing an increase in the demand for irrigation water, inevitably accompanied by an increase in the use of others resources like nitrogen fertilizers. Nitrogen is associated with negative economic and environmental impacts, which requires particularly important decision-making in terms of its application to meet crop needs. The agronomic efficiencies of water and nitrogen vary widely among different environments and can be modified due to management practices. However, some studies suggest that agronomic practices alone are not sufficient to entirely avoid nitrogen losses. In irrigated cropping systems, where classical nitrogen fertilizers are partially applied through irrigation water, Enhanced Efficiency Fertilizers (EEF), namely slow release and controlled release products, and nitrification inhibitors, have the potential to reduce nitrogen losses, contributing to higher resource-use efficiencies. This work aims to provide an overview of the possibilities of successfully using this type of fertilizers in irrigated agriculture, especially in Mediterranean climate regions, and the need for research in this field.
\end{abstract}

Keywords: Irrigation; Fertilization; EEF; WUE; NUE

Abbreviations: Cs: Temperate climate with dry Summer or Mediterranean climate (according to Köppen classification); EEF: Enhanced Efficiency Fertilizers; NUE: Nitrogen Use Efficiency; WUE: Water Use Efficiency

Agriculture faces two great challenges:

i.the need to meet the growing world food demand,

ii.while decreasing agriculture's global environmental footprint $[1,2]$.

At the same time, the agricultural sector must strength itself to face the risks associated with climate change, particularly in susceptible regions where water irregularity and scarcity is a key issue [3-7].

In regions with a Mediterranean climate there is typically a large variability and irregularity in the distribution of annual and inter-annual rainfall with a mild wet season trough autumn and Winter months and a dry season in the summer months. The balance between the key climate variables that characterize Mediterranean or Temperate climates with a dry Summer (Cs, according to Köppen classification)and the development period of a large number of agricultural plant species implies that the success of the agricultural sector in Mediterranean regions and other regions with water availability constraints depends to a very large degree on proper water management, suitable fertilizer applications, as well as on the success of irrigation implementation $[8,9]$. With the development of large irrigation schemes in these regions farmers are gradually resorting to irrigation, resource-use is growing and a profound change of the agricultural landscape is taking place within new irrigation areas. In fact, as a result of agriculture intensification, a growing demand for irrigation water has been inevitably accompanied by an increase in the use of others resources, like nitrogen fertilizers. In addition, there is a growing pressure on farmers to increase the cropping systems efficiency, and often doing it without the knowledge and the necessary assistance for the adoption of the best strategies and practices in a changing agriculture [10].

Nitrogen is the fourth most abundant nutrient in plants and nitrogen fertilization is needed because soils normally have insufficient nitrogen to meet the crops needs. The requirements of nitrogen by crops vary throughout their development cycle. The effect of the application of nitrogen depends very much on the crop development stage. If nitrogen is supplied to the crops in a fractional and gradual way, it will be more completely metabolized, 
minimizing the occurrence of soluble forms such as the nitrate ion (NO3-) [11]. Water availability and nitrogen supply to crops are factors in close interaction, affecting plant growth and their productive responses. Suitable nitrogen fertilization promotes leaf area and vegetation cover expansion, thus increasing the evapotranspiration efficiency of plants [12].For the large majority of cultivated plants, adequate nitrogen supply is required to achieve high yields, but negative effects from improper nitrogen fertilizer use threaten environmental quality and human health at both local and global scales as a result of water pollution from nitrate leaching or runoff, air pollution and greenhouse gas emissions [13].

Two of the major losses of nitrogen in the soil are due to gaseous losses denitrification and leaching. Denitrification losses contribute to global warming and the destruction of the ozone layer. Leaching losses affect the quality of soil, water and can interfere with human and animal health. Agriculture is considered to be the main source of contamination of the waters with nitrogen, accounting for more than half of the nitrate ion losses to groundwater $[12,13]$. It is suspected that the ingestion of high levels of nitrate, both in water and in food products rich in nitrates, may be associated with the formation of carcinogens of the nitrosamines type, and lead to the onset of cancer in the digestive tract. In young children and in ruminants, the consumption of water or foods rich in nitrates may also lead to their conversion into nitrite ion by bacteria in the stomach [12]. Thus, although there are doubts about the real risks to human health of nitrate ion intake, legislation in European Union countries, like Portugal, imposes a maximum nitrate ion content in

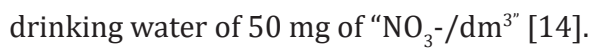

Crop yield response to water and nitrogen vary widely among different environments, and they can be shifted due to technological, environmental, or economic factors [9,13]. In order to meet the needs of crops and improve water use efficiency (WUE) as well as nitrogen use efficiency (NUE) of the cropping systems it is necessary to find a compromise in management between the quantitative and the qualitative aspects [15]. A wide range of fertilizers, known as Enhanced Efficiency Fertilizers (EEFs), are commercially advertised as improvers of nitrogen use by crops. These kinds of fertilizers, that delay the bioavailability of nitrogen in the soil, matching its release with the crops higher needs periods, are classified as:

i. Slow-release fertilizers (obtained as condensation products of urea and urea aldehydes);

ii. Controlled-release fertilizers (products containing a conventional fertilizer whose nutrient release in the soil is regulated by sulphur or/and polymer coatings);

iii. Stabilized fertilizers (which are modified during the production process with a nitrification inhibitor).

Several studies have shown that the use of such fertilizers has been successful in conditions of high rainfall and in sandy soils [16].

Irrigation is a major factor that influences $\mathrm{N}$ leaching [17]. In irrigated crops, where classic nitrogen fertilizers are partially applied through the irrigation water, EFFs have the potential to reduce leaching risks, thereby contributing to the increase of resource-use efficiency, both by promoting higher yields and reducing water and fertilizer inputs. For example, higher yields were found in irrigated wheat with a controlled release nitrogen fertilizer when compared to conventional split applied urea throughout the crop growing cycle [16]. Despite its large apparent advantages, the use of EEFs in agriculture has been lower due to doubts regarding the cost / benefit ratio and the insufficient demonstration of its advantages over conventional fertilizers $[18,19]$. Taking all this in consideration, finding both optimal irrigation and nitrogen application strategies, that is, finding a dynamic balance between these factors, adapting them to the very specific needs of each crop, it's a significant contribution not only to maintain soil and groundwater quality but also to preserve food safety and agriculture sustainability. For this purpose, more research on this topic should be carried out in order to study the best management options in the use of EEFs, especially in the most important Mediterranean irrigated crops.

\section{Acknowledgement}

This work is a contribution to the Project INTERATrigo (POCI01-0145-FEDER-023262; LISB0A-01-0145-FEDER-023262) and to the Project UID/GEO/04035/2013, funded by FCT - Fundação para a Ciência e a Tecnologia, Portugal.

\section{References}

1. Bruinsma J (2009) The resource outlook to 2050: By how much do land, water and crop yields need to increase by 2050? Expert Meeting on How to Feed the World in 2050.

2. Mueller ND, Gerber JS, Johnston M, Ray DK, Ramankutty N, Foley JA (2012) Closing yield gaps through nutrient and water management. Nature 490: 254-257.0lesen J0, Bindi M (2002) Consequences of climate change for European agricultural productivity, land use and policy. European J Agron 16: 239-262.

3. Zwart SJ, Bastiaanssen WGM (2004) Review of measured crop water productivity values for irrigated wheat, rice, cotton and maize. Agric Water Manag 69: 115-133.

4. Reidsma P, Ewert F, Lansink AO, Leemans R (2009) Vulnerability and adaptation of European farmers: a multi-level analysis of yield and income responses to climate variability. Reg Environ Change 9: 25-40.

5. Valverde P, Serralheiro R, Carvalho M, Maia R, Oliveira B, Ramos V (2005) Climate change impacts on irrigated agriculture in the Guadiana riverbasin (Portugal). Agric Water Manag 152: 17-30.

6. Li M, Guo P, Singh VP (2016) An efficient irrigation water allocation model under uncertainty. Agric Syst 144: 46-57.

7. Pereira LS, Cordery I, Iacovides I (2012) Improved indicators of water use performance and productivity for sustainable water conservation and saving. Agric Water Manag 108: 39-51.

8. Tomaz A, Patanita M, Guerreiro I, Boteta L, Ferro Palma J (2017) Water use and productivity of maize-based cropping systems in the Alqueva region (Portugal). Cereal Res Commun 45(4): 711-721.

9. McNie EC (2007) Reconciling the supply of scientific information with user demands: an analysis of the problem and review of the literature. Environ Sci Policy 10: 17-38.

10. Varenes A (2003) Produtividade dos Solos e Ambiente. Escolar Editora. Lisboa. 
11. Hay RKM, Walker AJ (1989) An introduction to the physiology of crop yield. Longman Scientific \& Technical. New York: John Wiley \& Sons, Inc, New York, USA.

12. Cassman KG, Dobermann A, Walters DT, Yang H (2003) Meeting Cereal Demand While Protecting Natural Resources and Improving Environmental Quality. Annual Review of Environment and Resources 28: 315-358.

13. Diário da República, Portaria n.. 259/2012 de 28 de agosto. 1. ${ }^{a}$ série N.o 166 - 28 de agosto de 2012.

14. Chen D, Suter H, Islam A, Edis R, Freney JR, Walker CN (2008) Prospects of improving efficiency of fertilizer nitrogen in Australian agriculture: a review of enhanced efficiency fertilizers. Aust J of Soil Res 46(4): 289301.
15. Olson-Rutz K, Jones C, Dinkins CP (2011) Enhanced Efficiency Fertilizers. Montana State University. EB0188.

16. Maharjan B, Venterea RT, Rosen C (2014) Fertilizer and Irrigation Management Effects on Nitrous Oxide Emissions and Nitrate Leaching. Agron J 106(2): 703-713.

17. Guertal EA (2009) Slow-release nitrogen fertilizers in vegetable production: A Review. Hortechnology 19(1): 16-19.

18. Arrobas M, Parada MJ, Magalhães P, Rodrigues MA (2011) Nitrogen-use efficiency and economic efficiency of slow-release $\mathrm{N}$ fertilizers applied to irrigated turfs in a Mediterranean environment. Nutr Cycl Agro ecosyst 89: 329-339.



